\title{
Agronomic performance of white oats cultivated under fertigation with treated sewage effluent and definition of critical limits of Normalized Difference Vegetation Index
}

Anderson Prates Coelho*, Rogério Teixeira de Faria, Aline Michelle da Silva Barbosa, Alexandre Barcellos Dalri, David Luciano Rosalen

Universidade Estadual Paulista “Júlio de Mesquita Filho”- Faculdade de Ciências Agrárias e Veterinárias - Departamento de Engenharia Rural, Jaboticabal (SP), Brazil.

ABSTRACT: One of the benefits of irrigation with wastewater in agriculture is the reduction in the use of mineral fertilizers and the increase in crop yield. For wastewater application, the use of remote sensing can help to define specific management areas. The aim of this study was to evaluate the yield and the growth of irrigated white oats (Avena sativa L.) with varying treated sewage effluent (TSE) levels. These attributes were then correlated with Normalized Difference Vegetation Index (NDVI) values obtained at four phenological stages of the crop and used to define critical limits of NDVI. The experiment consisted of five TSE treatments differing in irrigation depths (11, 31, 60, 87, and 100\%). Mean NDVI values in the crop were determined with an active terrestrial sensor (GreenSeeker), which were then correlated with height, maximum leaf area index (LAI), panicles per square meter, number of grains per panicle, grain mass, grain yield (GY), and biomass yield (BY). In order to define the NDVI critical limits, NDVI values were generated as a function of relative BY in four phenological stages; NDVI values at $90 \%$ and $110 \%$ of relative BY were considered critical. Maximum GY $\left(5.775 \mathrm{~kg} \cdot \mathrm{ha}^{-1}\right)$ and BY $\left(20,731 \mathrm{~kg} \cdot \mathrm{ha}^{-1}\right)$ of white oats were achieved with TSE-induced nitrogen rates of $45 \mathrm{~kg} \cdot \mathrm{ha}^{-1}$ and $88 \mathrm{~kg} \cdot \mathrm{ha}^{-1}$, respectively. NDVI readings were highly correlated (greater than 0.85 ) with growth and yield of white oats. In this study, we defined the critical NDVI limits of white oats and obtained maximum precision at the phenological stage 10.5.4.

Key words: Avena sativa L., biomass, modeling, NDVI, remote sensing. 


\section{INTRODUCTION}

In the world, $9.8710^{6}$ ha of land is under oat (Avena sativa L.) cultivation, with a total production of $23.7310^{6}$ $\mathrm{Mg}$, and an average yield of $2.41 \mathrm{Mg} \cdot \mathrm{ha}^{-1}$ (USDA 2018). Brazil is the fifth largest producer in the world and has steadily increased the area of land allocated to oat production in the last 10 years (CONAB 2018). Based on its nutritional composition (62\% carbohydrates and $11 \%$ crude protein) (Chepulis et al. 2017) and crop characteristics, white oat is considered an excellent option for animal feeding and cultivation in the Brazilian winter. In a no-tillage system, the straw produced by oats is directly correlated to the yield of subsequent summer crops, making it very suitable for this system (Damian et al. 2017).

A large area of Brazil exhibits low rainfall during winter, which may limit crop production. Under irrigation, grain yield and biomass of white oats reached 52\% and 37\%, respectively (Jat et al. 2017; Panasiewicz et al. 2017). To achieve greater environmental sustainability, systems, water sources, and irrigation management should be used to optimize the amount of water applied to crops. In this context, the use of wastewater in agriculture, such as treated sewage effluent (TSE), can increase the availability of quality water for other activities.

The use of TSE as irrigation water is a promising alternative to meet the water and nutritional demand of plants (Gonçalves et al. 2017). It can completely eliminate the need for nitrogen fertilization, as well as the majority of potassium fertilization in crops, which leads to greater yield than that with mineral fertilization (Fortes Neto et al. 2013; Santos et al. 2017a). The application of TSE increases soil fertility (Rosa et al. 2017), and does not detract it from its physical properties (Andrews et al. 2016), especially in regions with high crop yield due to humid climates. This generates a large amount of nutrients and vegetal residues that promote improvements in the physical quality of soil. Another advantage to TSE application in the soil is the reduction in contamination of water courses that would directly receive the residue. TSE contains high nutrient and organic carbon content and can lead to eutrophication of water courses (Cai et al. 2013).

Irrigation with wastewater is increasingly prevalent in Brazil, and its effects on the nutrition of most crops are still poorly understood. The factors that contribute to the soil-plant-atmosphere system are complex, and geotechnologies can be used to define fertigation in areas where this residue is used. Through remote sensing, vegetation indexes such as Normalized Difference Vegetation Index (NDVI) can be used to define the application of variable rate inputs and specific management zones. This technique is necessary, since the amount of sewage generated in cities is limited, which limits its use as TSE. A potential solution to this problem would be to dilute TSE with water in order to increase the maximum area that can be irrigated with it. Since NDVI readings are highly correlated with soil fertility (Sultana et al. 2014), areas with higher NDVI values may receive less TSE without affecting their crop yields.

The aims of this study were to evaluate the yield and the growth of irrigated white oats with treated sewage effluent (TSE), and to correlate these attributes with vegetation index readings (NDVI) obtained at four phenological stages of the crop, as well as to define critical limits of NDVI.

\section{MATERIAL AND METHODS}

The experiment was conducted at the experimental farm of the School of Agricultural and Veterinarian Sciences, São

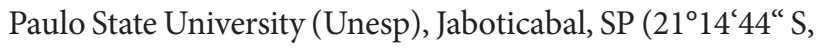
$48^{\circ} 17^{\circ} 00^{\prime \prime} \mathrm{W}$ and $545 \mathrm{~m}$ alt). According to the Köppen classification, the climate of this region is of the Aw type; it is subtropical with an annual average temperature of $22^{\circ} \mathrm{C}$. It has also relatively dry winters and summer rains; its annual average rainfall is $1,424 \mathrm{~mm}$ (Alvares et al. 2013). The soil of the experimental area is classified as eutrophic Red Oxisol (Embrapa 2013). Table 1 describes the physical and chemical attributes of this soil type.

White oat ('IAC 7') was sown on May 09, 2017, at a density of $80 \mathrm{~kg} \cdot \mathrm{ha}^{-1}$ and $0.17 \mathrm{~m}$ spacing between lines, in an area previously cultivated with Urochloa brizantha 'Marandu'. Liming was performed 30 days before the experiment, at a rate of $1.5 \mathrm{t} \cdot \mathrm{ha}^{-1}$ limestone with a relative power of total neutralization (PRNT) of 80. Soil preparation was done using conventional methods, and was performed by two graders. Plants were fertilized with $20 \mathrm{~kg} \cdot \mathrm{ha}^{-1}$ of N, $160 \mathrm{~kg} \cdot \mathrm{ha}^{-1}$ of $\mathrm{P}_{2} \mathrm{O}_{5}$ and $80 \mathrm{~kg} \cdot \mathrm{ha}^{-1}$ of $\mathrm{K}_{2} \mathrm{O}$. N fertilization was performed according to the water demand of the crop, through TSE application.

The maximum and minimum average temperatures for the period before and after flowering were $26.4^{\circ} \mathrm{C}$ and $13.8^{\circ} \mathrm{C}$, and $27.2^{\circ} \mathrm{C}$ and $13.1^{\circ} \mathrm{C}$, respectively (Fig. 1a). The maximum daily temperature observed was $33.6^{\circ} \mathrm{C}$, while the minimum temperature observed was $7.2^{\circ} \mathrm{C}$. 
Table 1. Physical and chemical attributes of the soil in the experimental area.

\begin{tabular}{|c|c|c|c|c|c|c|c|c|c|c|c|c|}
\hline \multirow{2}{*}{$\begin{array}{l}\text { Depth } \\
\text { (m) }\end{array}$} & \multirow{2}{*}{$\begin{array}{l}\text { Soil density } \\
\left(\mathrm{g} \cdot \mathrm{cm}^{-3}\right)\end{array}$} & Field Capacity & Perman & itting point & \multirow{2}{*}{\multicolumn{2}{|c|}{ Sand }} & \multirow{2}{*}{\multicolumn{2}{|c|}{$\begin{array}{c}\text { Clay } \\
\left(\mathbf{g} \cdot \mathbf{k g}^{-1}\right)\end{array}$}} & \multirow{2}{*}{\multicolumn{2}{|c|}{ Silt }} & \multirow{2}{*}{\multicolumn{2}{|c|}{ Soil texture }} \\
\hline & & & \multicolumn{2}{|l|}{$\left(\mathrm{m}^{3} \cdot \mathrm{m}^{-3}\right)$} & & & & & & & & \\
\hline $0.00-0.20$ & 1.45 & 0.45 & \multicolumn{2}{|c|}{0.33} & \multicolumn{2}{|c|}{310} & \multicolumn{2}{|c|}{470} & \multicolumn{2}{|c|}{220} & \multicolumn{2}{|c|}{ Clayed } \\
\hline $0.20-0.40$ & 1.49 & 0.41 & & & \multicolumn{2}{|c|}{270} & \multicolumn{2}{|c|}{530} & \multicolumn{2}{|c|}{200} & \multicolumn{2}{|c|}{ Clayed } \\
\hline \multirow{2}{*}{$\begin{array}{l}\text { Depth } \\
\text { (m) }\end{array}$} & \multirow{2}{*}{$\begin{array}{c}\mathbf{p H} \\
\mathrm{CaCl}_{2}\end{array}$} & O.M. & Presin & $\mathbf{S}$ & $\mathbf{H}+\mathbf{A l}$ & Al & $\mathbf{K}$ & $\mathrm{Ca}$ & Mg & SB & CEC & \multirow{2}{*}{$\begin{array}{l}\text { BS } \\
\%\end{array}$} \\
\hline & & g.dm ${ }^{-3}$ & & $\left(\mathrm{~m}^{-3}\right)$ & & & & lolc. & & & & \\
\hline $0.00-0.20$ & 5.6 & 40 & 67 & 5 & 21 & 1 & 3.4 & 36 & 13 & 52.7 & 73.9 & 71 \\
\hline $0.20-0.40$ & 5.8 & 40 & 68 & 5 & 20 & 1 & 3.2 & 36 & 11 & 50.3 & 70.4 & 71 \\
\hline \multirow{2}{*}{$\begin{array}{l}\text { Depth } \\
\text { (m) }\end{array}$} & \multicolumn{2}{|r|}{ B } & \multicolumn{2}{|r|}{$\mathrm{Cu}$} & & \multicolumn{2}{|c|}{$\mathrm{Fe}$} & \multicolumn{2}{|c|}{ Mn } & \multicolumn{3}{|c|}{$\mathbf{Z n}$} \\
\hline & \multicolumn{12}{|c|}{$\mathrm{mg} \cdot \mathrm{dm}^{-3}$} \\
\hline $0.00-0.20$ & \multicolumn{2}{|r|}{0.33} & \multicolumn{2}{|r|}{6.7} & & \multicolumn{2}{|c|}{53} & \multicolumn{2}{|c|}{23.6} & \multicolumn{3}{|c|}{5.6} \\
\hline $0.20-0.40$ & \multicolumn{2}{|c|}{0.31} & \multicolumn{2}{|r|}{5.5} & & \multicolumn{2}{|c|}{42} & \multicolumn{2}{|c|}{21} & \multicolumn{3}{|c|}{4.6} \\
\hline
\end{tabular}

q: Moisture based on volume; SB: sum of bases; CEC: cation exchange capacity; BS: base saturation; O.M.: organic matter.
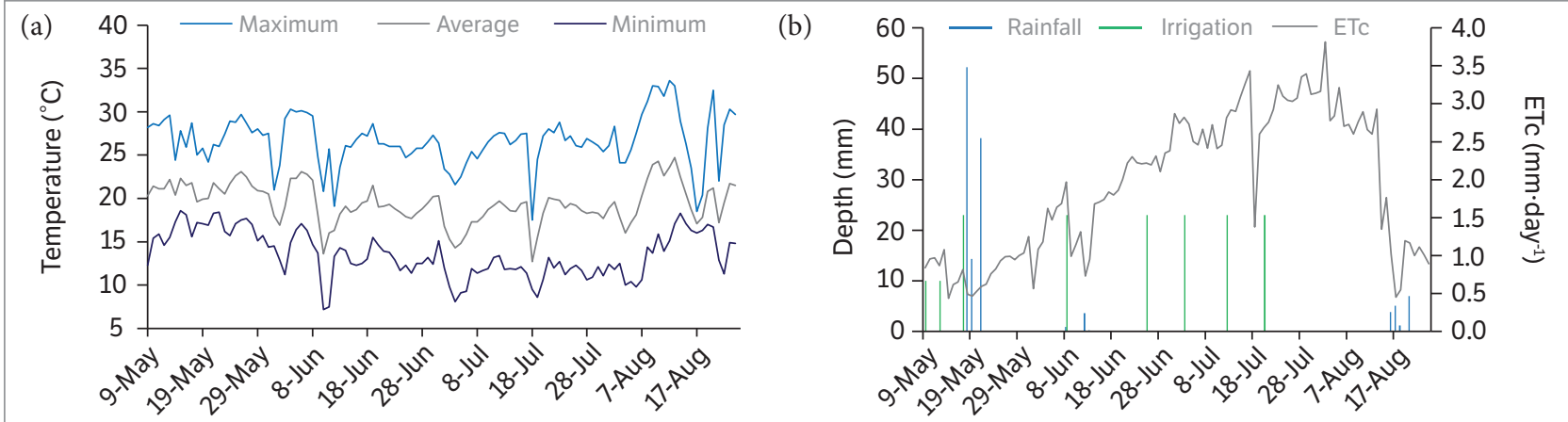

Figure 1. Maximum, minimum, and average daily temperature (a) and rainfall, crop evapotranspiration (ETc), and daily irrigation (b) temperatures between May 9, 2017 and August 24, 2017.

The accumulated evapotranspiration of the oat crop (ETc) was $207.4 \mathrm{~mm}$, with a maximum value of $3.82 \mathrm{~mm} \cdot$ day $^{-1}$, while the cumulative rainfall was $126.6 \mathrm{~mm}$. The applied depth, through irrigation, was $158 \mathrm{~mm}$; the amount of TSE was in accordance with the levels defined by each treatment (Fig. 2). The highest volume of rainfall was accumulated at the beginning of crop development. Therefore, irrigation supplementation was essential for high yields during this period.

The physical and chemical attributes of the TSE, for the calculation of the amount of nutrients applied, were as follows: Ntotal $=60 \mathrm{mg} \cdot \mathrm{L}^{-1}, \mathrm{P}=4.4 \mathrm{mg} \cdot \mathrm{L}^{-1}, \mathrm{~K}=14.6 \mathrm{mg} \cdot \mathrm{L}^{-1}$, $\mathrm{Ca}=12.2 \mathrm{mg} \cdot \mathrm{L}^{-1}, \mathrm{Mg}=3.9 \mathrm{mg} \cdot \mathrm{L}^{-1}$, FeTotal $=0.4 \mathrm{mg} \cdot \mathrm{L}^{-1}$, $\mathrm{Mn}=0.1 \mathrm{mg} \cdot \mathrm{L}^{-1}, \mathrm{Zn}=0.1 \mathrm{mg} \cdot \mathrm{L}^{-1}, \mathrm{Na}=52.0 \mathrm{mg} \cdot \mathrm{L}^{-1}$, $\mathrm{S}^{-\mathrm{SO}_{4}}{ }_{4}^{2-}=19.3 \mathrm{mg} \cdot \mathrm{L}^{-1}, \mathrm{TOC}($ total organic carbon $)=44.0 \mathrm{mg} \cdot \mathrm{L}^{-1}$, $\mathrm{pH}=7.3$, and electric conductivity $(\mathrm{EC})=0.48 \mathrm{dS} \cdot \mathrm{m}^{-1}$.

The "Line source" experimental design was used; a central line was used to distribute TSE and two external lines were used to apply water. This experimental design distributed irrigation water and TSE in such a way that the applied depth was uniform at the center of the experimental area, but with variable TSE application rates (Lauer 1983). The TSE application rate varied in the perpendicular direction to the line of sprinklers; the TSE concentration decreased down the line of sprinklers, ranging from high to zero (only water) (Fig. 2). Five TSE treatments (E1, E2, E3, E4, and E5) received $11,31,60,87$, and $100 \%$ of TSE, respectively.

Senninger Model 3023-2 sprinklers with 3/4 "M 08Qx05 nozzles were used. The installation spacing was $6 \mathrm{~m}$ between the sprinklers and $12 \mathrm{~m}$ between the lateral lines. Water intensity of the sprinklers for the respective spacing was measured in the field and was found to be $12 \mathrm{~mm} \cdot \mathrm{h}^{-1}$. The coefficients of application uniformity (CUC) and water distribution (CUD) of the irrigation system were determined to be $89 \%$ and $84 \%$, respectively. The precipitation distribution factor of the sprinklers in the field was defined according 


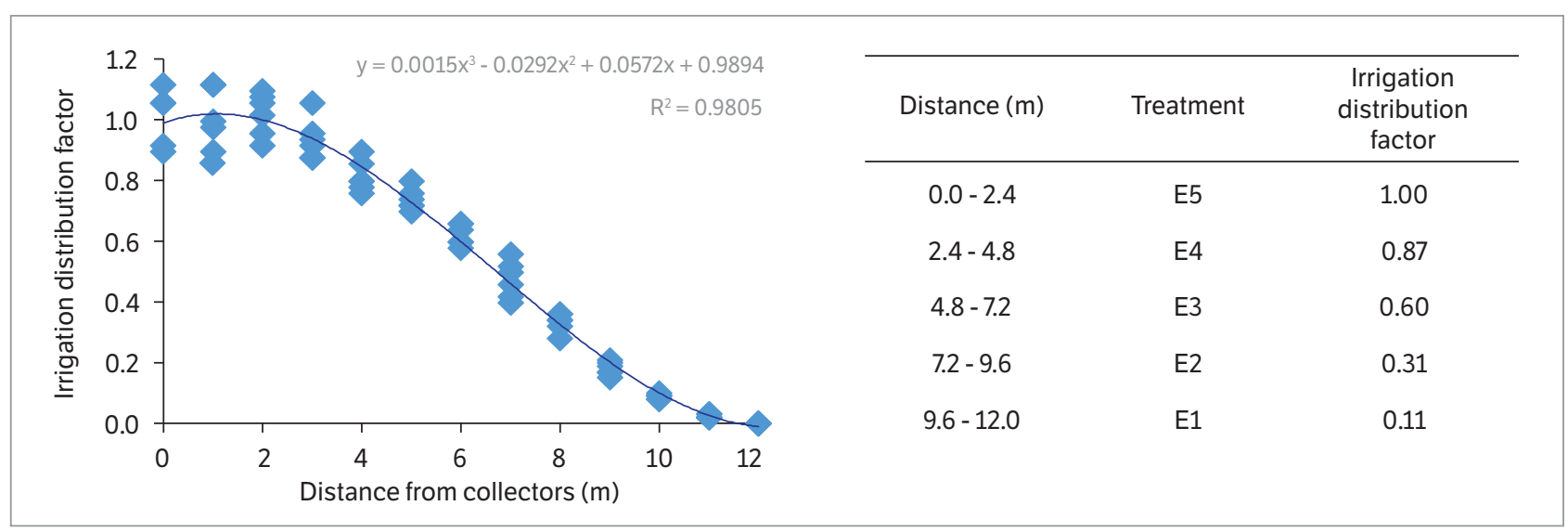

Figure 2. Irrigation distribution fractions obtained in field tests. Sprinklers are presented as a function of distance or irrigation line treatments; sprinklers spaced $6 \mathrm{~m}$ on the line, and $12 \mathrm{~m}$ between the rows.

to the treatments (Fig. 2). The experimental plots were $4.5 \mathrm{~m}$ long and $2.4 \mathrm{~m}$ wide, with a total area of $216 \mathrm{~m}^{2}$ $(24 \mathrm{~m} \times 9 \mathrm{~m}) ; 0.5 \mathrm{~m}$ on each side of the plot was used to define the outer border.

Irrigation management was carried out based on the water demand of the crop and per FAO-56 method, using daily climatic data obtained from the automated agrometeorological station. The reference evapotranspiration (ETo) was daily estimated using the Penman-Monteith equation (Allen et al. 1998). The ETc was calculated using the ETo product and the crop coefficients (Kc), as described by Allen et al. (1998).

Irrigation was performed whenever the soil water deficit reached $23 \mathrm{~mm}$. This depth was calculated as a function of the Kc of white oats and soil physical attributes, based on soil retention limits (Table 1 ). To define the evapotranspiration water depth, a $0.40 \mathrm{~m}$ root depth and a $50 \%$ soil water availability factor were used (Allen et al. 1998).

The terrestrial sensor used to determine the vegetation index was GreenSeeker HandHeldTM, portable. This sensor automatically generates NDVI readings from the spectral response of the red $(650 \mathrm{~nm})$ and near infrared $(770 \mathrm{~nm})$ bands (Eq. 1). Measurement with GreenSeeker was manually performed, with passage over the white oats. All treatment readings were obtained from a mean height of 0.5-0.8 $\mathrm{m}$ between the sensor and the target, and were performed in $5.9 \mathrm{~m}^{2}$ areas $(9.8 \mathrm{~m}$ linear displacement on the experimental unit, multiplied by the useful width of $0.6 \mathrm{~m}$ captured by the sensor). The average value from 20 to $30 \mathrm{NDVI}$ measurements was determined for each plot according to the Eq. 1:

$$
\text { NDVI }=\rho \text { nir }-\rho r / \rho n i r+\rho r
$$

where NDVI: vegetation index by normalized difference; pnir: near infrared reflectance $(770 \mathrm{~nm})$; pr: red reflectance $(650 \mathrm{~nm})$.

The NDVI index was determined at four phenological stages: pseudocaule appearance (4), rubbery (8), flag leaf sheath appearance (10), and watery ripe kernel (10.5.4), according to the phenology scale for winter cereals by Feeks and Large (Large 1954). Each replicate presented a mean NDVI value and was correlated to grain yield (GY), biomass yield (BY), plant height, maximum leaf area index (LAI), panicles per square meter, number of grains per panicle, and mass of 1000 grains of each plot.

The GY of the white oats was calculated by taking a $2 \mathrm{~m}^{2}$ area of useful plot and standardizing the moisture of grains

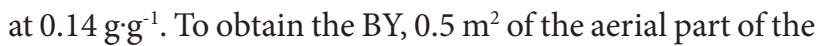
plants in each useful plot was harvested. They were dried in a forced circulation oven at $65^{\circ} \mathrm{C}$ for $72 \mathrm{~h}$ to obtain dry matter. The maximum value of LAI was used in the correlation analysis with the NDVI readings and was obtained during the flag leaf sheath appearance stage (10) of white oat. LAI was determined using a nondestructive method. Width and length of 5 leaves per plot were measured and multiplied by a factor 0.72 . This factor was determined based on the actual area of the sheet over the area defined by the product between the measured width and length (rectangle). The plant height in each plot was determined based on an average of 5 plants. The yield components (panicles per square meter, number of grains per panicle, and mass of 1000 grains) were determined in a harvested area of $0.5 \mathrm{~m}^{2}$ per plot.

Linear correlations between the NDVI readings and growth and yield of white oats were evaluated using the Pearson's correlation coefficient. 
The definition of index response ranges for white oat yields was based on that described by Vian et al. (2018). In this analysis, The NDVI plots were plotted as a function of relative biomass yield (RBY) for each phenological stage evaluated. The RBY was calculated as a function of the average biomass yield of 20 plots. From this, three management zone ranges were defined; "low," "average," and "high" yield were those whose indexes generated less than $90 \%$, between $90 \%$ and $110 \%$, and more than $110 \%$ of the RBY, respectively.

Data were subjected to analysis of variance (Test F); significant was set at the $5 \%$ probability level. The Duncan averages comparison test was applied at the $5 \%$ probability level. Statistical analyzes were performed in AgroEstat software (Barbosa and Maldonado Júnior 2015).

\section{RESULTS AND DISCUSSION}

The amount of nutrients and sodium applied in each treatment are listed in Table 2. The treatments E1, E2, E3, and $\mathrm{E} 4$ contained $11,31,60$, and $87 \%$ of nutrients apllied in the E5 treatment (Fig. 2), respectively. It was observed that after $\mathrm{N}$, the second highest element applied to the soil via TSE was $\mathrm{Na}$, which carries the risk of soil salinization. However, the TSE method was shown to only present a small risk of salinization to the soil in a study by Santos et al. (2017a), in which the authors verified the effect of the application of TSE in a long period on the chemical properties of the same soil studied in the present work.

Table 2. Amount of nutrients and sodium applied in soil cultivated with white oats under each treatment with variable level of treated sewage effluent (TSE).

\begin{tabular}{cccccc}
\hline $\begin{array}{c}\text { Amount applied } \\
\left(\mathbf{k g}^{-} \mathbf{h a}^{-1}\right)\end{array}$ & $\mathbf{E 1}$ & $\mathbf{E 2}$ & $\mathbf{E 3}$ & $\mathbf{E 4}$ & $\mathbf{E 5}$ \\
\hline $\mathrm{N}$ & 10.43 & 29.39 & 56.88 & 82.48 & 94.80 \\
\hline $\mathrm{P}$ & 0.77 & 2.17 & 4.20 & 6.09 & 7.00 \\
\hline $\mathrm{K}$ & 2.54 & 7.15 & 13.84 & 20.07 & 23.07 \\
\hline $\mathrm{Ca}$ & 2.12 & 5.98 & 11.58 & 16.79 & 19.30 \\
\hline $\mathrm{Mg}$ & 0.67 & 1.89 & 3.66 & 5.31 & 6.10 \\
\hline $\mathrm{S}$ & 1.12 & 3.16 & 6.12 & 8.87 & 10.20 \\
\hline $\mathrm{Fe}$ & 0.06 & 0.16 & 0.30 & 0.44 & 0.50 \\
\hline $\mathrm{Mn}$ & 0.01 & 0.03 & 0.06 & 0.09 & 0.10 \\
\hline $\mathrm{Zn}$ & 0.02 & 0.06 & 0.12 & 0.17 & 0.20 \\
\hline $\mathrm{Na}$ & 9.04 & 25.48 & 49.32 & 71.51 & 82.20 \\
\hline
\end{tabular}

E1-11\% TSE; E2 - 31\% TSE TE; E3 - 60\% TSE; E4 - 87\% TSE; E5 - 100\% TSE.
The amount of N, P and K extracted from white oats is approximately $115 \mathrm{~kg} \cdot \mathrm{ha}^{-1}, 13 \mathrm{~kg} \cdot \mathrm{ha}^{-1}$ and $150 \mathrm{~kg} \cdot \mathrm{ha}^{-1}$,

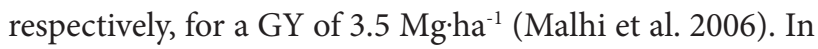
this study, the amount of $\mathrm{P}$ was fully supplied, and the amount of $\mathrm{K}$ was supplied to a large extent by sowing fertilization for all treatments; applied $\mathrm{P}_{2} \mathrm{O}_{5}$ and $\mathrm{K}_{2} \mathrm{O}$ were $160 \mathrm{~kg} \cdot \mathrm{ha}^{-1}$ $\left(70 \mathrm{~kg} \cdot \mathrm{ha}^{-1} \mathrm{P}\right)$ and $80 \mathrm{~kg} \cdot \mathrm{ha}^{-1}\left(66 \mathrm{~kg} \cdot \mathrm{ha}^{-1} \mathrm{~K}\right)$, respectively. Therefore, the amount of $\mathrm{P}$ and $\mathrm{K}$ applied by the TSE, in relation to the total amount applied for the treatments, was lower than that of $\mathrm{N}$; the seed rate for $\mathrm{N}$ was only $20 \mathrm{~kg} \cdot \mathrm{ha}^{-1}$.

Top dressing fertilization by TSE based on water demand of the crop can increase fertilization, as nutrient demand is higher when the plant has a higher water requirement. In addition, a positive correlation was observed between the nutrient uptake curve and water requirement of crops (Somaweera et al. 2016). Due to nutrient dynamics in the soil, the possibility of $\mathrm{N}$ split application by TSE presents advantages, such as reducing losses and providing the largest amount of nutrient in stages with higher demand, as discussed previously.

The number of panicles per square meter ranged from 439 to 507 , and was not affected ( $p>0.05$ ) by the TSE levels (Table 3 ). The height of the plants was influenced by the treatments, with the TSE E1 plants having lower height than those in other treatments; a similar trend was observed for the number of grains per panicle (NGP). For mass of 1000 grains (M1000), the treatments E4 (87\% TSE) and E5 (100\% TSE) were inferior to the others. The maximum leaf area index (maximum LAI) was 100\% higher for the E5 treatment than for the E1 (11\% TSE). For GY, plants in the treatments E2 (31\% TSE) and E3 (60\% TSE) presented higher average than those in other treatments, whereas the BY was not influenced by the TSE levels.

Plant density is an essential factor of GY in white oats. A higher number of panicles per square meter increases the GY of white oats to a certain extent (Dornelles et al. 2018), since high densities increase intraspecific competition among tillers. For cultivar 'IAC 7' (the same as that used in the present study), densities between 410 and 500 panicles $\cdot \mathrm{m}^{-2}$ generated a GY ranging from 5,241 to 7,024 kg.ha- (Soratto et al. 2012); this range was observed for the number of panicles per square meter in the present study.

Only the E1 treatment (11\% TSE) presented a number of grains per panicle smaller than the others $(p<0.05)$. Since this treatment received less amount of TSE, the amount of nutrients applied by TSE did not meet the needs of the 
Table 3. Comparison of yield averages, growth components, and yield of white oats as a function of treated sewage effluent levels, and linear Pearson's correlations between the variables and NDVI readings at phenological stages.

\begin{tabular}{|c|c|c|c|c|c|c|c|}
\hline \multirow{2}{*}{ Treatment } & \multirow{2}{*}{$\begin{array}{c}\text { Number of } \\
\text { panicles per } \mathbf{m}^{2}\end{array}$} & \multirow{2}{*}{$\begin{array}{l}\text { Height } \\
\text { (cm) }\end{array}$} & \multirow{2}{*}{$\begin{array}{c}\text { Number of grains } \\
\text { per panicles }\end{array}$} & \multirow{2}{*}{$\begin{array}{l}\text { M1000 } \\
\text { (g) }\end{array}$} & \multirow{2}{*}{$\underset{\text { (maximum) }}{\text { LAI }}$} & GY & BY \\
\hline & & & & & & \multicolumn{2}{|c|}{$\left(\mathbf{k g} \cdot h a^{-1}\right)$} \\
\hline E1 & 439 & $118 \mathrm{~B}$ & $36.88 \mathrm{~B}$ & $63.8 \mathrm{~A}$ & $4.06 \mathrm{C}$ & $4,693 \mathrm{~B}$ & 15,356 \\
\hline E2 & 507 & $138 \mathrm{~A}$ & $45.94 \mathrm{~A}$ & $65.5 \mathrm{~A}$ & $4.82 \mathrm{C}$ & $5,604 \mathrm{~A}$ & 19,117 \\
\hline E3 & 502 & $142 \mathrm{~A}$ & $45.25 \mathrm{~A}$ & $62.9 \mathrm{~A}$ & $6.01 \mathrm{~B}$ & $5,803 \mathrm{~A}$ & 19,068 \\
\hline E4 & 502 & $141 \mathrm{~A}$ & $45.88 \mathrm{~A}$ & $55.1 \mathrm{~B}$ & $6.22 \mathrm{~B}$ & $4,389 \mathrm{~B}$ & 20,843 \\
\hline E5 & 490 & $137 \mathrm{~A}$ & $46.75 \mathrm{~A}$ & $50.6 \mathrm{~B}$ & $8.13 \mathrm{~A}$ & $3,905 \mathrm{~B}$ & 20,804 \\
\hline $\mathrm{F}$ & $0.30 \mathrm{~ns}$ & 6.00 ** & $2.97^{\star}$ & $163.33^{\star *}$ & $19.10^{\star *}$ & $9.70^{\star \star}$ & $1.13 \mathrm{~ns}$ \\
\hline CV (\%) & 19.01 & 8.31 & 12.48 & 11.24 & 26.00 & 19.10 & 19.13 \\
\hline Phenological stages & \multicolumn{7}{|c|}{ Correlation of NDVI readings with yield and yield components } \\
\hline 4 & $0.10 \mathrm{~ns}$ & $0.73^{\star \star}$ & $0.69^{\star}$ & $0.30 \mathrm{~ns}$ & $0.86^{\star \star}$ & $0.88^{\star \star}$ & $0.74^{\star \star}$ \\
\hline 8 & $0.38 \mathrm{~ns}$ & $0.83^{\star \star}$ & $0.83^{\star \star}$ & $0.37 \mathrm{~ns}$ & $0.86^{\star \star}$ & $0.90^{\star \star}$ & $0.74^{\star \star}$ \\
\hline 10 & $0.39 \mathrm{~ns}$ & $0.91^{\star \star}$ & $0.90^{* *}$ & $0.28 \mathrm{~ns}$ & $0.86^{\star \star}$ & $0.90^{\star *}$ & $0.85^{\star *}$ \\
\hline 10.5 .4 & $0.42 n s$ & $0.91^{\star \star}$ & $0.88^{\star \star}$ & $0.29 \mathrm{~ns}$ & $0.87^{\star \star}$ & $0.94^{\star \star}$ & $0.82^{\star \star}$ \\
\hline
\end{tabular}

LAI - leaf area index - $\mathrm{m}^{2} \cdot \mathrm{m}^{-2}$; M1000 - mass of 1000 grains; GY - grain yield; BY - biomass yield; E1 - 11\% TSE; E2 - 31\% TSE; E3 - 60\% TSE; E4 - 87\% TSE; E5 $100 \%$ TSE; * Significant at the $5 \%$ probability level; **Significant at $1 \%$ probability level; ns - Not significant; Equal letters in the column do not differ by Duncan's test (5\% probability); Stage 4 pseudocaule appearance; Stage 8 - rubbery; Stage 10 - Flag Leaf sheath appearance; Stage 10.5.4 - kernel watery ripe.

crop, especially for $\mathrm{N}$, influencing this attribute of yield. For the E1 treatment, the amount of $\mathrm{N}$ applied in topdressing was $10.4 \mathrm{~kg} \cdot \mathrm{ha}^{-1}$, a value $65 \%$ lower than that applied in the E2 treatment (29.4 kg.ha-1) (Table 2), justifying the smallest number of grains per panicle compared to the other treatments.

Generally, grain mass is affected only when water deficit occurs (Akram et al. 2013), a fact not verified in the present study. However, in the kernel watery ripe stage (10.5.4), the $\mathrm{E} 4$ and $\mathrm{E} 5$ treatments resulted in lodging, and affected grain filling, which justified the lower averages for these treatments. Due to the higher stalk height of plants in these treatment groups during the oat cycle, irrigation in the kernel watery ripe stage (10.5.4) led to lodging, caused by the weight of the water on oat canopies in the treatments E4 and E5.

Due to the lodging of plants in the treatments E4 and E5, the average plant height were low during the crop harvest (Table 3). It was observed that only the treatment E1 resulted in lower plant height $(\mathrm{p}<0.05)$, probably due to small amount of nutrients applied during this treatment. An effective way of controlling the lodging of white oats without interfering with their yield is to use growth regulators (Marolli et al. 2017). In addition, the use of small-sized plants and regionallyadapted genotypes may decrease lodging of the crop.

The treatment E5 (100\% TSE) resulted in the highest maximum LAI (8.13) and was superior to all other treatments $(\mathrm{p}<0.01)$. There was a positive correlation between maximum LAI and $\mathrm{N}$ rates during the TSE topdressing application, with lower values for the treatment $\mathrm{E} 1$ and higher values for the treatment E5. It was proposed that higher $\mathrm{N}$ rates promote greater elongation and leaf length, thus increasing LAI (Akmal et al. 2010).

For GY, the treatment E3 (5803 kg.ha- $\left.{ }^{-1}\right)$ was statistically superior to E1 (4693 kg.ha-1), E4 (4389 kg.ha-1) and E5 $\left(3905 \mathrm{~kg} \cdot \mathrm{ha}^{-1}\right)$, and equal to E2 $\left(5604 \mathrm{~kg} \cdot \mathrm{ha}^{-1}\right)(\mathrm{p}<0.01)$. The amount of $\mathrm{N}$ supplied to white oats by TSE for the treatments E3 and E2 was $57 \mathrm{~kg} \cdot \mathrm{ha}^{-1}$ and $29 \mathrm{~kg} \cdot \mathrm{ha}^{-1}$, respectively. As there was no statistically significant difference in GY between these treatments, TSE may show higher dilution in water (31\% TSE) without reducing the yield of white oats. The advantage to dilution in water is the increased TSE irrigation area. In addition, irrigation with TSE allows nutrients to be supplied to plants in critical phenological stages, which reduces nutrient losses through volatilization and leaching (Santos et al. 2017a).Correlations between the NDVI readings and growth and yield of oats were not significant for number of panicles per square meter and mass of 1000 grains ( $p>0.05)$. As lodging in the treatments E4 and E5 influenced the mass of 1000 grains, only plots subjected to the treatments $\mathrm{E} 1, \mathrm{E} 2$, and E3 (12 in total) were used to correlate this attribute with NDVI values. The results indicated that the NDVI values were highly correlated with height, number of 
grains per panicle, maximum LAI, GY, and BY; the highest correlations were observed in the phenological stages 10 and 10.5.4 of the crop.

As NDVI readings show a direct correlation with nutrient accumulation in plants, especially in relation to $\mathrm{N}$ (Santos et al. 2017 b), high correlations between yield and growth attributes with mean NDVI values were expected and were observed in the present study. Plants without nutritional stress have greater height and LAI (Wasternack 2014). In addition, the production capacity of these plants increased, which directly interferes with the number of grains per panicle (Soratto et al. 2012). Evaluations in maximum biomass accumulation stages presented higher correlation and precision in estimating crop yield attributes (Wang et al. 2014). As nutritional need increases with the course of the crop cycle until it reaches a peak, diagnosis of nutrient deficiencies is usually more precise in stages near the flowering stage of the crop (Rhezali and Lahlali 2017).

Due to wavelengths emitted by an active optical sensor, NDVI values provide estimates of chlorophyll content present in leaves (Zarco-Tejada et al. 2013). The chlorophyll content is influenced by the amount of $\mathrm{N}$ absorbed by plants. However, the excessive consumption of this nutrient does not interfere with the chlorophyll content (Geng et al. 2014). Thus, from a determined N rate, NDVI values will not show significant increases. In the present study, the maximum NDVI values observed in the phenological stages $4,8,10$, and 10.5 .4 were $0.51,0.84,0.85$, and 0.84 , respectively, and were obtained with TSE N rates of $94.3 \mathrm{~kg} \cdot \mathrm{ha}^{-1}, 73.3 \mathrm{~kg} \cdot \mathrm{ha}^{-1}$, $84.0 \mathrm{~kg} \cdot \mathrm{ha}^{-1}$, and $83.6 \mathrm{~kg} \cdot \mathrm{ha}^{-1}$, respectively (Fig. 3). As NDVI readings at more advanced stages of the crop cycle show greater correlation with the final GY (Rhezali and Lahlali 2017), it was determined that the recommended $\mathrm{N}$ rates by TSE for white oats is approximately $85 \mathrm{~kg} \cdot \mathrm{ha}^{-1}$ (stages 10 and 10.5.4).

According to the models (Fig. 4a,b), the maximum points for $\mathrm{GY}$ and $\mathrm{BY}$ of white oats occurred at $\mathrm{N}$ rates of $45.3 \mathrm{~kg} \cdot \mathrm{ha}^{-1}$ and $88 \mathrm{~kg} \cdot \mathrm{ha}^{-1}$, respectively. For BY, it was noted that the $\mathrm{N}$ rate that guaranteed the maximum BY (Fig. 4) was close to the rate that guaranteed the highest NDVI value (Fig. 3). As discussed previously, lodging of the $\mathrm{E} 4$ and $\mathrm{E} 5$ treatment plots reduced the oat grain mass by directly interfering with the GY (Fig. 4a). Therefore, the GY was lower for these treatments as compared with those of other treatments. Up to the treatment E3, there was a positive correlation between GY and rates of $\mathrm{N}$ by
TSE; the maximum GY was obtained at a $\mathrm{N}$ rate that was lower as compared with that observed for BY.

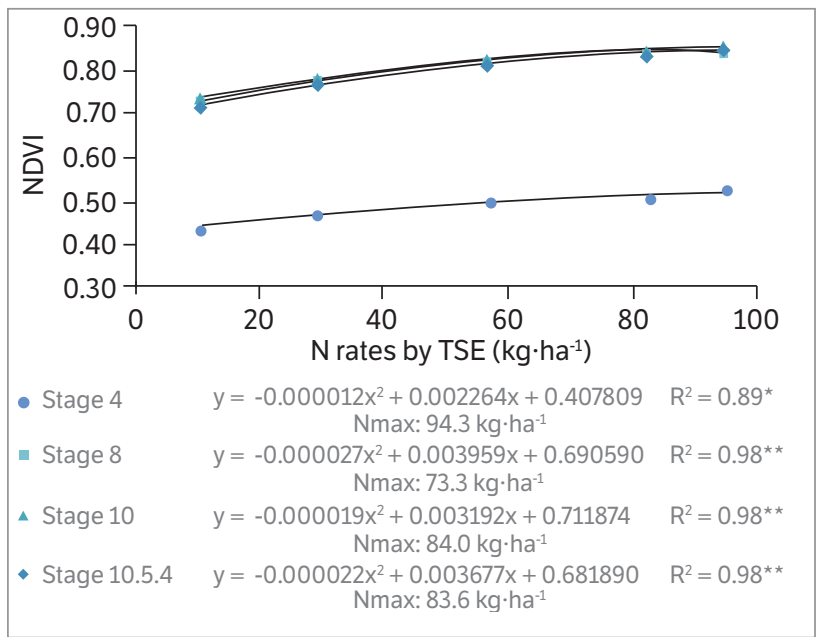

Figure 3. Variation in NDVI values as a function of the $\mathrm{N}$ rates provided by TSE for white oats in four phenological stages. * Significant at $5 \%$ probability; ${ }^{* *}$ Significant at $1 \%$ probability.

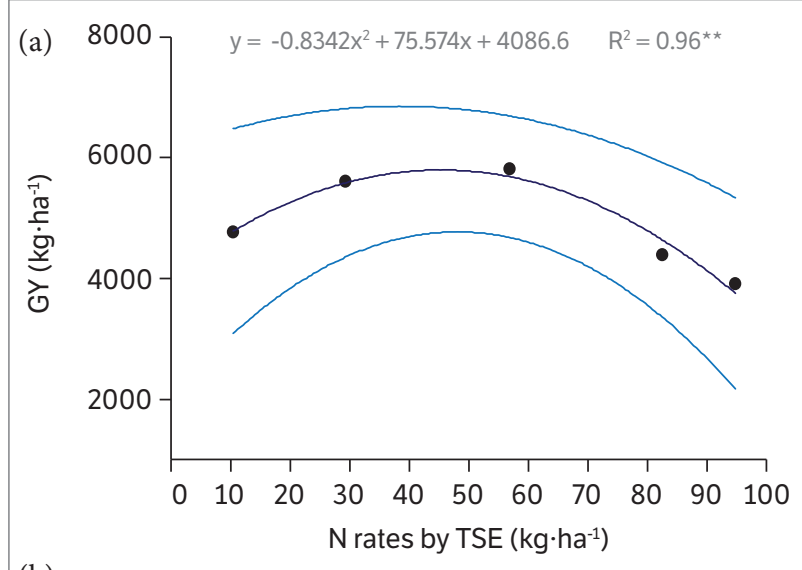

(b)

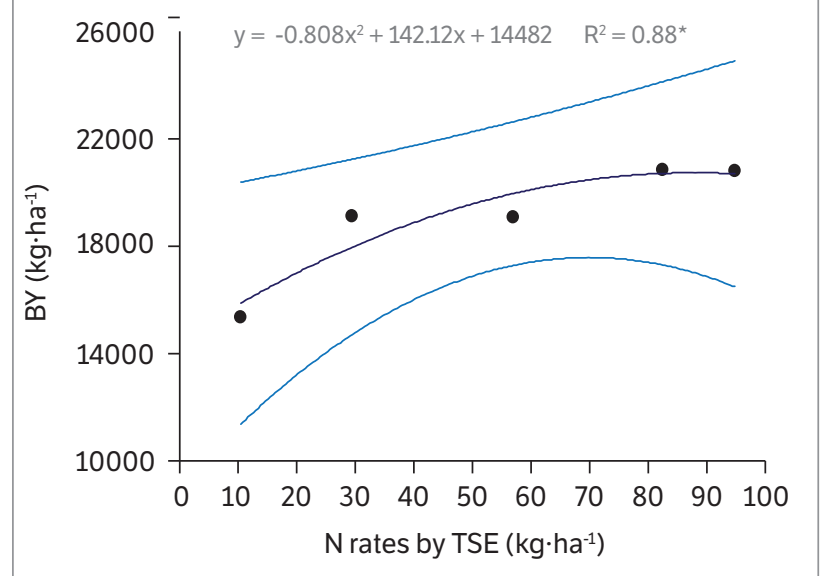

Figure 4. Models of estimated grain yield - $G Y(a)$ and biomass - BY (b) of white oats as a function of the N rates applied by treated sewage effluent (TSE) with respective confidence intervals ( $95 \%$ probability); * Significant at $5 \%$ probability; ${ }^{* \star}$ Significant at $1 \%$ probability. 
There was no decrease in BY at the lodging of the treatments E4 and E5, as lodging occurred at an advanced phenological stage of the crop cycle, during which the majority of the crop biomass was already accumulated. Based on regression analysis, GY and BY of the white oats without top dressing fertilization would be 4,086.6 $\mathrm{kg} \cdot \mathrm{ha}^{-1}$ and 14,482 $\mathrm{kg} \cdot \mathrm{ha}^{-1}$, respectively.

Evaluating the $\mathrm{N}$ rates of topdressing for white oats under two succession systems and at three years, Silva et al. (2016) observed that the $\mathrm{N}$ rate of $60 \mathrm{~kg} \cdot \mathrm{ha}^{-1}$ was the most indicated for oat crop. According to the authors, at rates equivalent to and greater than this, increases in GY are minimal; these increases are independent of the succession system and whether or not the year is climatically favorable for oats. According to the same authors, the maximum difference between grain yield for the $\mathrm{N}$ rate of $60 \mathrm{~kg} \cdot \mathrm{ha}^{-1}$ and the maximum recommended technical rate $\left(119 \mathrm{~kg} \cdot \mathrm{ha}^{-1}\right)$ was only $348 \mathrm{~kg} \cdot \mathrm{ha}^{-1}$, which is economical. The rate recommended by the authors was close to the treatment rate observed in the present study $\left(\mathrm{E} 3=56.9 \mathrm{~kg} \cdot \mathrm{ha}^{-1}\right)$, which guaranteed the maximum GY of white oats (5,803 kg.ha-1) (Fig. 4).

The same was not observed for BY, where the maximum rate of $\mathrm{N}$ by TSE $\left(88 \mathrm{~kg} \cdot \mathrm{ha}^{-1}\right)$ and the maximum BY $\left(20,731 \mathrm{~kg} \cdot \mathrm{ha}^{-1}\right)$ were different from that observed for GY. This may be due to the lodging of the treatments E4 and E5 that reduced their GY. However, the $\mathrm{N}$ rate that guarantees maximum GY may not be the same rate that guarantees maximum BY. From a given point, increasing $\mathrm{N}$ fertilization does not significantly increase grain yield of oats, but the response to BY may be significant (Silva et al. 2016). Therefore, defining the use of white oats (grains or biomass for grazing) is essential for management of TSE fertilization in this crop.

The growth of cotton (Gossypium hirsutum L.) under the TSE and water was evaluated according to the water demand of the crop by Bezerra and Fideles Filho (2009), who observed higher leaf area and biomass in plants irrigated by TSE. In addition, growth was highly correlated with NDVI values. In addition, Rissini et al. (2015) observed high correlation between wheat (Triticum sativum L.) yield and NDVI readings from the beginning of crop development. According to the authors, it is important to take into account only the readings performed at the beginning of the cycle, since biotic and abiotic factors in later phenological stages may compromise the yield of grains and biomass.

In defining the critical limits of NDVI in white oats crops, it was observed that all the regressions generated were significant, and were independent of the phenological stage (Fig. 5). The highest precision of fit was for the most advanced phenological stages, with a higher coefficient of determination $\left(\mathrm{R}^{2}\right)$ for the stage 10.5.4. Thus, it is recommended that TSE management areas be defined according to the NDVI critical values of white oats at phenological stages near the flowering stage of the crop to ensure greater accuracy.

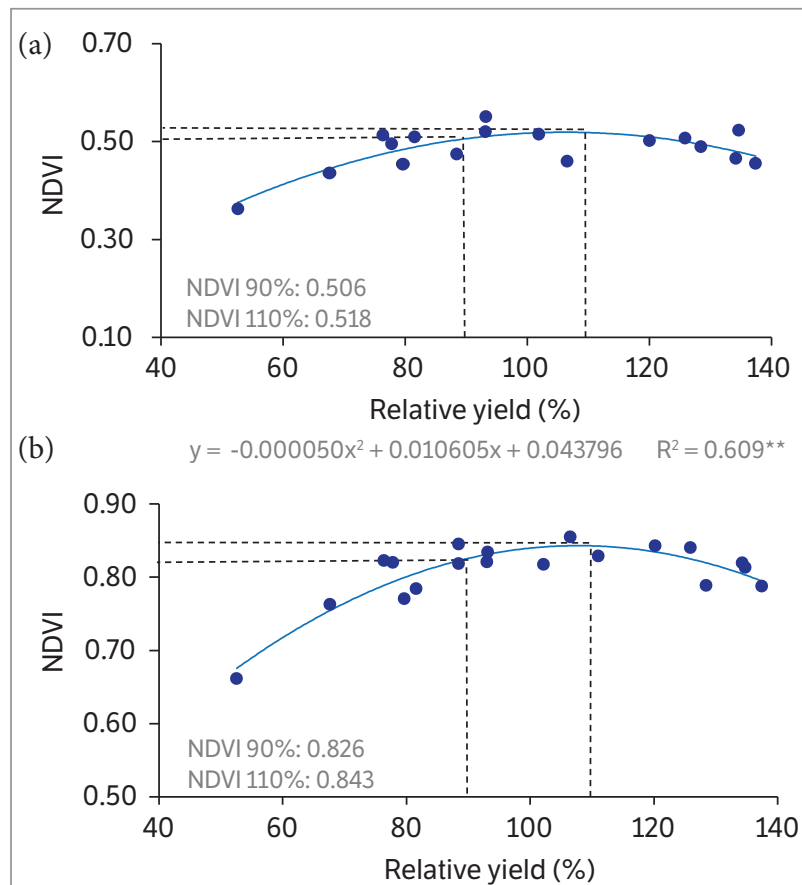

(c) $y=-0.000055 x^{2}+0.011862 x+0.203762 \quad R^{2}=0.805^{\star \star}$

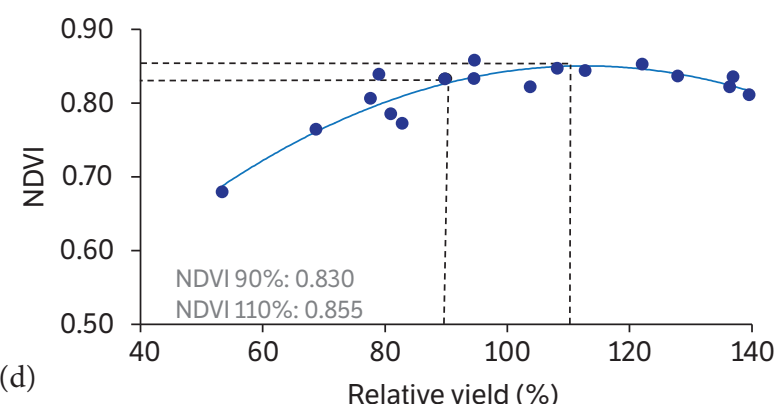

(d)

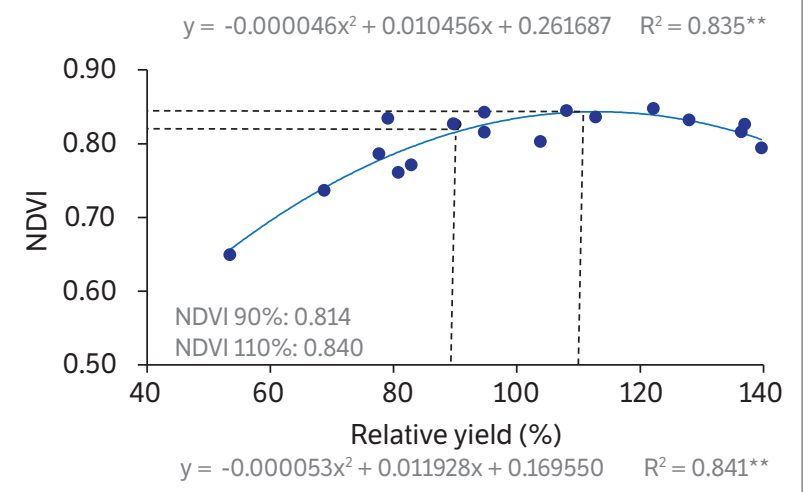

Figure 5. Definition of critical NDVI ranges for white oats in phenological stages 4 (a), 8 (b), 10 (c), and 10.5.4 (d), according to the phenological scale of Feeks and Large (Large, 1954). ${ }^{* \star}$ Significant at $1 \%$ probability. 
Due to the higher year-to-year variability of NDVI values in early phenological stages of the crop (Grohs et al. 2011), the use of certain critical limits at the beginning of crop development may lead to less precision. In addition, for winter cereals, the definition of critical values as a function of GY may show greater variation as compared with that of BY, since GY presents greater year-on-year variations (Grohs et al. 2011). In irrigated crops, as in the present study, this is largely because climatic factors such as temperature and radiation have more effects on flowering and filling of grains than on biomass accumulation (Silva et al. 2016).

The critical limits for obtaining high yield classes at phenological stage 8 observed for white oats (Avena sativa L.) in the present study were similar to those observed for other winter grains such as wheat (Triticum sativum L.) and barley (Hordeum vulgare L.). For wheat and barley, the critical NDVI limit for high yields ranged from 0.80 to 0.83 (Grohs et al. 2009). These values were dependent on the summer crop predecessor and were similar to those observed in the present study for the same phenological stage (0.84). This indicated that for winter cereals, there are no large variations in critical NDVI values required to obtain high yields. This may be due to the similarity of cultivation and growth of the crops, as evidenced by Grohs et al. (2009), since the authors did not need individual models for each species in defining the critical limits.

With the classes of yield defined according to the critical limits of NDVI, management practices such as irrigation and nitrogen fertilization at variable rates can be implemented. This can be done by adopting, for the "High" class, the amount of water that provides $100 \%$ of the ETc and the recommended rate of the recommended fertilizer for the crop; this percentage can be increased for the "Average" and "Low" yield classes. In addition, it is necessary to define models of variation of NDVI values as a function of irrigation depth and $\mathrm{N}$ rates for each crop.

\section{CONCLUSION}

The maximum grain yield ( $\left.5.775 \mathrm{~kg} \cdot \mathrm{ha}^{-1}\right)$ and biomass yield (20.731 kg.ha- $\left.{ }^{-1}\right)$ of white oats (Avena sativa L.) were reached with treated sewage effluent-mediated nitrogen rates of $45 \mathrm{~kg} \mathrm{ha}^{-1}$ and $88 \mathrm{~kg} \cdot \mathrm{ha}^{-1}$, respectively. The NDVI readings showed high correlation with growth and yield attributes of white oats, with greater values in phenological stages near the flowering of the crop (10 and 10.5.4). The critical NDVI limits of white oats were obtained with higher evaluation precision at the phenological stage 10.5.4, with the "Low" yield class corresponding to NDVI values lower than 0.814 , the "Mean" yield class between 0.814 and 0.840 , and the "High" yield class with values greater than 0.840 .

\section{AUTHORS' CONTRIBUTION}

Conceptuaization, Coelho A. P. and Faria R. T.; Methodology, Coelho A. P. and Barbosa A. M. S.; Investigation, Coelho A. P., Faria R. T. and Barbosa A. M. S.; Writing Original Draft, Coelho A. P.; Writing - Review and Editing, Dalri A. B. and Rosalen D. L.; Supervision, Faria R. T.

\section{ORCID IDS}
A.P. Coelho
(D) https://orcid.org/0000-0003-2472-9704
R.T. Faria
(DD https://orcid.org/0000-0002-1696-7940
A.M.S. Barbosa
https://orcid.org/0000-0001-8336-2645
A.B. Dalri
(iD) http://orcid.org/0000-0002-3122-1899
D.L. Rosalen
(iD) http://orcid.org/0000-0003-1759-9673

\section{REFERENCES}

Akmal, M., Rehman, H., Farhatullah, M. A. and Akbar, H. (2010). Response of maize varieties to nitrogen application for leaf area profile, crop growth, yield and yield components. Pakistan Journal of Botany, 42, 1941-1947.
Akram, H. M., Ali, A., Sattar, A., Rehman, H. S. U. and Bibi, A. (2013). Impact of water deficit stress on various physiological and agronomic traits of three basmati rice (Oryza sativa L.) cultivars. Journal of Animal and Plant Sciences, 23, 1415-1423. 
Allen, R. G., Pereira, L. S., Raes, D. and Smith, M. (1998). Crop evapotranspiration - Guidelines for computing crop water requirements. (FAO Irrigation and Drainage Paper 56). Rome: FAO.

Alvares, C. A., Stape, J. L., Sentelhas, P. C., Gonçalves, J. L. M. and Sparovek, G. (2013). Koppen's climate classification map for Brazil. Meteorologische Zeitschrift, 22, 711-728. https://doi. org/10.1127/0941-2948/2013/0507

Andrews, D. M., Robb, T., Elliott, H. and Watson, J. E. (2016). Impact of long-term wastewater irrigation on the physicochemical properties of humid region soils: "The Living Filter" site case study. Agricultural Water Management, 178, 239-247. https://doi. org/10.1016/j.agwat.2016.10.001

Barbosa, J. C. and Maldonado Júnior, W. (2015). AgroEstat-Sistema para análises estatísticas de ensaios agronômicos. Versão 1.0. Jaboticabal: Departamento de Ciências Exatas.

Bezerra, B. G. and Fideles Filho, J. F. (2009). Análise de crescimento da cultura do algodoeiro irrigada com águas residuárias. Revista Ciência Agronômica, 40, 339-345.

Cai, T., Park, S. Y. and Li, Y. (2013). Nutrient recovery from wastewater streams by microalgae: status and prospects. Renewable and Sustainable Energy Reviews, 19, 360-369. https://doi.org/10.1016/j. rser.2012.11.030

Chepulis, L., Hill, S. and Mearns, G. (2017). The nutritional quality of New Zealand breakfast cereals: an update. Public Health Nutrition, 20, 3234-3237. https://doi.org/10.1017/S1368980017002397

[CONAB] Companhia Nacional de Abastecimento. (2018). Acompanhamento da safra brasileira: grãos. Quinto Levantamento, 5 (5) 142p. fevereiro/2018. Brasília: CONAB.

Damian, J. M., Santi, A. L., Fornari, M., Da Rosa, C. O. and Eschner, V. L. (2017). Monitoring variability in cash-crop yield caused by previous cultivation of a cover crop under a no-tillage system. Computers and Electronics in Agriculture, 142, 607-621. https:// doi.org/10.1016/j.compag.2017.11.006

Dornelles, E. F., Kraisig, A. R., Silva, J. A., Sawicki, S., Roos-Frantz, F. and Carbonera, R. (2018). Artificial intelligence in seeding density optimization and yield simulation for oat. Revista Brasileira de Engenharia Agrícola e Ambiental, 22, 183-188. https://doi. org/10.1590/1807-1929/agriambi.v22n3p183-188

[EMBRAPA] Empresa Brasileira de Pesquisa Agropecuária. (2013). Sistema brasileiro de classificação de solos. 3 ed. Brasília: Embrapa Agropecuária.
Fortes Neto, P., Veiga, P. G. A., Fortes, N. L. P., Targa, M. S., Gadioli, J. L. and Peixoto, P. H. M. (2013). Alterações químicas do solo e produção de aveia fertilizada com água residuária do tratamento de esgoto sanitário. Ambiente \& Água, 8, 71-83. https://doi. org/10.4136/ambi-agua.1368

Geng, X., Guillard, K., Mangiafico, S. S. and Morris, T. F. (2014). Defining sufficiency levels of nitrogen in cool-season turfgrass lawns using Macy's concept. Crop Science, 54, 844-1858. https:// doi.org/10.2135/cropsci2013.11.0737

Gonçalves, I. Z., Barbosa, E. A. A., Santos, L. D. S., Nazário, A. A., Feitosa, D. R. C., Tuta, N. F. and Matsura, E. E. (2017). Water relations and productivity of sugarcane irrigated with domestic wastewater by subsurface drip. Agricultural Water Management, 185, 105-115. https://doi.org/10.1016/j.agwat.2017.01.014

Grohs, D. S., Bredemeier, C., Mundstock, C. M. and Poletto, N. (2009). Modelo para estimativa do potencial produtivo em trigo e cevada por meio do sensor GreenSeeker. Engenharia Agrícola, 29,101-112. https://doi.org/10.1590/S0100-69162009000100011

Grohs, D. S., Bredemeier, C., Poletto, N. and Mundstock, C. M. (2011). Validação de modelo para predição do potencial produtivo de trigo com sensor óptico ativo. Pesquisa Agropecuária Brasileira, 46, 446-449. https://doi.org/10.1590/S0100-204X2011000400015

Jat, H., Kaushik, M. K., Nepalia, V.and Singh, D. (2017). Effect of irrigation schedule and nitrogen fertilization on growth, yield and quality of fodder oat (Avena sativa L.). Journal of Pharmacognosy and Phytochemistry, 6, 2040-2042.

Large, E. C. (1954). Growth stages in cereals illustration of the Feekes scale. Plant Pathology, 3, 128-129. https://doi. org/10.1111/j.1365-3059.1954.tb00716.x

Lauer, D. A. (1983). Line-Source Sprinkler Systems for Experimentation with Sprinkler-Applied Nitrogen Fertilizers 1. Soil Science Society of America Journal, 47, 124-128. https://doi.org/10.2136/ sssaj1983.03615995004700010025x

Malhi, S. S., Johnston, A. M., Schoenau, J. J., Wang, Z. L. and Vera, C. L. (2006). Seasonal biomass accumulation and nutrient uptake of wheat, barley and oat on a Black Chernozem soil in Saskatchewan. Canadian Journal of Plant Science, 86, 1005-1014. https://doi. org/10.4141/P05-116

Marolli, A., Silva, J. A., Romitti, M. V., Mantai, R. D., Hawerroth, M. C. and Scremin, O. B. (2017). Biomass and grain yield of oats by growth regulator. Revista Brasileira de Engenharia Agrícola e 
Ambiental, 21, 163-168. https://doi.org/10.1590/1807-1929/agriambi. v21n3p163-168

Panasiewicz, K., Koziara, W. and Faligowska, A. (2017). Response of three oat forms to sprinkling irrigation and nitrogen fertilization. Turkish Journal of Field Crops, 22, 81-88.

Rhezali, A. and Lahlali, R. (2017). Nitrogen (N) Mineral Nutrition and Imaging Sensors for Determining N Status and Requirements of Maize. Journal of Imaging, 3, 51-60. https://doi.org/10.3390/ jimaging3040051

Rissini, A. L., Kawakami, J. and Genú, A. M. (2015). Índice de vegetação por diferença normalizada e produtividade de cultivares de trigo submetidas a doses de nitrogênio. Revista Brasileira de Ciência do Solo, 39, 1703-1715. https://doi.org/10.1590/01000683rbcs20140686

Rosa, D. M., Sampaio, S. C., Pereira, P. A., Reis, R. R. D. and Sbizzaro, M. (2017). Corn fertilization using swine wastewater and soil-water environmental quality. Engenharia Agrícola, 37, 401-810. https:// doi.org/10.1590/1809-4430-eng.agric.v37n4p801-810/2017

Santos, G. O., Faria, R. T. D., Rodriguês, G. A., Dantas, G. D. F., Dalri, A. B. and Palaretti, L. F. (2017a). Forage yield and quality of marandugrass fertigated with treated sewage wastewater and mineral fertilizer. Acta Scientiarum. Agronomy, 39, 515-523. https:// doi.org/10.4025/actasciagron.v39i4.32828

Santos, G. O., Rosalen, D. L. and Faria, R. T. (2017b). Use of active optical sensor in the characteristics analysis of the fertigated brachiaria with treated sewage. Engenharia Agrícola, 37, 1213-1221. https://doi.org/10.1590/1809-4430-eng.agric.v37n6p1213-1221/2017

Silva, J. A., Goi Neto, C. J., Fernandes, S. B., Mantai, R. D., Scremin, O. B. and Pretto, R. (2016). Nitrogen efficiency in oats on grain yield with stability. Revista Brasileira de Engenharia Agrícola e Ambiental, 20, 1095-1100. https://doi.org/10.1590/1807-1929/ agriambi.v20n12p1095-1100

Somaweera, K. A. T. N., Suriyagoda, L. D. B., Sirisena, D. N. and Costa, W. A. J. M. (2016). Accumulation and partitioning of biomass, nitrogen, phosphorus and potassium among different tissues during the life cycle of rice grown under different water management regimes. Plant and Soil, 401, 169-183. https://doi.org/10.1007/ s11104-015-2541-2

Soratto, R. P., Crusciol, C. A. C., Castro, G. S. A., Costa, C. H. M. D. and Ferrari Neto, J. (2012). Leaf application of silicic acid to white oat and wheat. Revista Brasileira de Ciência do Solo, 36, 1538-1544. https://doi.org/10.1590/S0100-06832012000500018

Sultana, S. R., Ali, A., Ahmad, A., Mubeen, M., Zia-Ul-Haq, M., Ahmad, S., Jaafar, H. Z. (2014). Normalized Difference vegetation index as a tool for wheat yield estimation: A case study from Faisalabad, Pakistan. The Scientific World Journal, 2014, 1-8. https://doi. org/10.1155/2014/725326

[USDA] United States Department of Agriculture (2018). World Agricultural Production. Circular Series. WAP 2-18, February. [Accessed 2018 February 20]. Available at: https://apps.fas.usda. gov/psdonline/circulars/production.pdf

Vian, A. L., Bredemeier, C., Silva, P. R. F., Santi, A. L. and Giordano, C. P.D. S. (2018). Limites críticos de NDVI para estimativa do potencial produtivo do milho. Revista Brasileira de Milho e Sorgo, 17, 91-100.

Wang, L., Tian, Y., Yao, X., Zhu, Y. and Cao, W. (2014). Predicting grain yield and protein content in wheat by fusing multi-sensor and multi-temporal remote-sensing images. Field Crops Research, 164, 178-188. https://doi.org/10.1016/j.fcr.2014.05.001

Wasternack, C. (2014). Action of jasmonates in plant stress responses and development-applied aspects. Biotechnology advances, 32 , 31-39. https://doi.org/10.1016/j.biotechadv.2013.09.009

Zarco-Tejada, P. J., González-Dugo, V., Williams, L. E., Suárez, L., Berni, J. Á., Goldhamer, D. and Fereres, E. (2013). A PRI-based water stress index combining structural and chlorophyll effects: Assessment using diurnal narrow-band airborne imagery and the CWSI thermal index. Remote sensing of environment, 138, 38-50. https://doi.org/10.1016/j.rse.2013.07.024 